\title{
Effects of different grassland restoration approaches on soil properties in the southeastern Horqin sandy land, northern China
}

\author{
Jiyou Yuan ${ }^{\mathrm{a}, \mathrm{b}}$, Zhiyun Ouyang $^{\mathrm{a}}$, Hua Zheng a,*, Weihua $\mathrm{Xu}^{\mathrm{a}}$ \\ a State Key Lab of Urban and Regional Ecology, Research Center for Eco-Environmental Sciences, Chinese Academy of Sciences, Beijing 100085, China \\ ${ }^{\mathrm{b}}$ Graduate University of Chinese Academy of Sciences, Beijing 100049, China
}

\section{A R T I C L E I N F O}

\section{Article history:}

Received 3 April 2011

Received in revised form 11 April 2012

Accepted 15 April 2012

\section{Keywords:}

Grassland

Restoration

Soil properties

China

\begin{abstract}
A B S T R A C T
In the semi-arid Horqin sandy grassland, continuous grazing has led to decreased ground cover. The bare land surface is then directly exposed to strong wind erosion, leading to desertification. Different restoration approaches have been used to recover these desertified sandy grasslands. This study compared soil properties subjected to different grassland restoration approaches, i.e., three restoration treatments and an unrestored control: FG, grassland enclosed by sheltering forest (Populus $\times$ beijingensis); MG, artificially sparse Pinus sylvestris var. mongolica grassland; UG, artificially sparse Ulmus pumila grassland; CK, desertified grassland. Soil samples were taken from depths of $0-20 \mathrm{~cm}$, and physical (i.e., bulk density, particle size distribution, waterholding capacity, total porosity), chemical (i.e., $\mathrm{pH}$, soil organic matter, total $\mathrm{N}$, total $\mathrm{P}$, total $\mathrm{K}$, available $\mathrm{N}$, available $\mathrm{P}$, available $\mathrm{K}$, cation exchange capacity, exchangeable $\mathrm{Ca}^{2+}$, exchangeable $\mathrm{Mg}^{2+}$, exchangeable $\mathrm{Na}^{+}$, exchangeable $\mathrm{K}^{+}$), and biological (i.e., microbial biomass carbon, substrate richness index, Shannon's diversity index) properties were selected as soil indicators. The three different approaches to grassland restoration were confirmed to alleviate wind erosion and enhance sand surface stabilization, as well as improve soil physicochemical and biological properties, in comparison with unrestored control. Soil physical, chemical, and biological properties in two types of artificial sparsely forested grassland were significantly better than those in grassland enclosed by shelter forest; however, there was no significant difference between the two types of artificial sparsely forested grassland. These results suggest that an artificial sparsely forested grassland restoration approach may be more effective at restoring the poor and arid soils of desertified sandy grasslands, such as the Horqin sandy land.
\end{abstract}

(c) 2012 Elsevier B.V. All rights reserved.

\section{Introduction}

The Horqin sandy grassland, located in the semiarid agropastoral transition zone between the Inner Mongolian Plateau and the Northeast Plain, is highly susceptible to environmental changes and is one of the areas of northern China most affected by desertification due to factors including intensive human disturbance from overcultivation, overgrazing, fuel collection, irrational use of water resources, and extreme climatic conditions (Sivakumar, 2007; Zhang et al., 2004; Zhu and Chen, 1994). Much of the Horqin sandy grassland is desertified. Desertification depletes natural environments and jeopardizes agricultural production and socio-economic development (Zhao et al., 2005; Zhu et al., 2007). Various methods of combating grassland desertification have been used successfully in the area since the 1950s. In recent years, the primary causes of desertification (primarily overgrazing) and restoration approaches (including degraded farmland to grassland and fenced enclosures) have been studied (Li et al., 2000, 2009; Su et al., 2004). In addition,

\footnotetext{
* Corresponding author. Tel.: +86 106284 9815; fax: +86 1062943822 .

E-mail address: zhenghua@rcees.ac.cn (H. Zheng).
}

the effectiveness of soil and vegetation restoration at combating desertification have been evaluated (Su and Zhao, 2003; Zhang et al., 2005; Zhao et al., 2007; Zhou et al., 2008). However, limited quantitative research has been carried out on the impacts on soil properties of artificial sparsely wooded grassland and fencing desertified sandy grassland.

Soils are living bodies with physical, chemical, and biological properties and processes that perform essential ecosystem services (Karlen et al., 2003). Through soil physical, chemical, and biological assessment, we can judge the effectiveness of sandy grassland restoration approaches. In this paper, we discuss the long-term impacts on soil properties of different approaches to restoring desertified sandy grassland in the southeastern Horqin sandy grassland. The objective of this study was to determine an effective and feasible approach for restoring desertified sandy grasslands.

\section{Methods}

\subsection{Study area}

The research was carried out at the Daqinggou Ecological Station, Institute of Applied Ecology, Chinese Academy of Sciences, 
Table 1

Vegetation properties of experimental sites in 2009. Means in a row followed by the same letter are not significantly different at $p<0.05$.

\begin{tabular}{|c|c|c|c|c|}
\hline Parameter & $\mathrm{FG}^{\mathrm{b}}$ & $\mathrm{UG}^{\mathrm{c}}$ & $\mathrm{MG}^{\mathrm{d}}$ & $\mathrm{CK}^{\mathrm{e}}$ \\
\hline Plant species richness & 39 & 35 & 40 & 20 \\
\hline Average tree height $(\mathrm{m})$ & 9.10 & 4.32 & 3.76 & - \\
\hline Biomass of aboveground tree $\mathrm{a}^{\mathrm{a}}$ & 295.99(26.46)a & $231.88(33.25) b$ & 279.99(30.06)a & - \\
\hline Biomass of underground tree $\mathrm{a}^{\mathrm{a}}$ & $239.09(38.84) a$ & $211.59(11.24) b$ & $226.78(41.30) a$ & - \\
\hline Biomass of aboveground herb ${ }^{a}$ & $269.98(49.92) a$ & $182.88(40.11) b$ & $206.57(42.07) b$ & $133.15(48.68) \mathrm{c}$ \\
\hline Biomass of underground herb ${ }^{a}$ & $207.09(38.29) b$ & $211.59(46.40) a$ & $226.78(46.40) a$ & $83.24(30.04) \mathrm{c}$ \\
\hline Biomass of standing litter ${ }^{\mathrm{a}}$ & 63.73(11.78)a & $61.52(13.49) a$ & 57.66(11.74)a & $60.8(21.92) a$ \\
\hline \multicolumn{5}{|l|}{ a Units: $\mathrm{g} \mathrm{m}^{-2}$} \\
\hline \multicolumn{5}{|c|}{ b FG, grassland fenced with a shelter forest. } \\
\hline \multicolumn{5}{|c|}{ c UG, sparse Ulmus pumila grassland. } \\
\hline \multicolumn{5}{|c|}{ d MG, sparse Pinus sylvestris var. mongolica grassland. } \\
\hline
\end{tabular}

in the southeastern Horqin sandy grassland, Kezuohou Banner, Inner Mongolia $\left(121^{\circ} 31^{\prime}-123^{\circ} 43^{\prime} \mathrm{E}, 42^{\circ} 40^{\prime}-43^{\circ} 42^{\prime} \mathrm{N}, 88.5-308.4 \mathrm{~m}\right.$ above sea level). The area has a continental monsoon climate, with an annual average temperature of $5.8^{\circ} \mathrm{C}$ (maximum: $23.8^{\circ} \mathrm{C}$ in July; minimum: $-15.1^{\circ} \mathrm{C}$ in January), and an accumulated active temperature $\geq 10^{\circ} \mathrm{C}$ of $3032-3168^{\circ} \mathrm{C}$. The annual daily mean sun duration is $2837-2892 \mathrm{~h}$, with global radiation of $120 \mathrm{kcal} / \mathrm{cm}^{2}$. The annual average wind speed is $3.2 \mathrm{~m} / \mathrm{s}$, and average annual precipitation is $450 \mathrm{~mm}$, with about $70 \%$ occurring between June and August.

This area of northern China is a typical agropastoral transition zone, containing many ecosystems, such as natural deciduous broadleaf forests, forest plantations, grasslands, wetlands, farmlands, etc. The main soil types are aeolian sandy soil and meadow soil, and the main vegetation types are fixed sand, semi-fixed sand, and mobile dune. The main plant species are psammophytes of the Mongolian and Huabei floras.

\subsection{Experimental design}

The experiment was conducted at the Daqinggou Ecological Station in 1992. The experiment had single-factor completely randomized design that compared three treatments to restore degraded grasslands. The treatments were: (1) grassland fenced with a shelter forest (Populus $\times$ beijingensis) (FG), in which the dominant species were Artemisia scoparia, Setaria viride, Agropyron cristatum, and Cleistogenes chinensis; (2) artificially sparse Pinus sylvestris var. mongolica grassland (MG), in which the dominant species were Cleistogenes chinensis, Setaria viride, Artemisia scoparia, and Calamagrostis arundinacea; and (3) artificially sparse Ulmus pumila grassland (UG), in which the dominant species were Setaria viride, Cleistogenes chinensis, Artemisia scoparia, and Artemisia lavandulaefolia. After tree planting, the grasslands were left alone to restore naturally, without human management or disturbance. Desertified sandy grassland, in which the dominant species were Agrophyllum squarrosum (Linn.) Moq. and Cenchrus echinatus Linn., was selected as a control (CK) site, these locations had also been established in 1992 and then left alone. Vegetation properties of four treatments in 2009 are shown in Table 1. Three replicates were set for each treatment randomly and 12 plots were selected finally. The area of plot was $200 \mathrm{~m} \times 200 \mathrm{~m}$. We collected 15 cores of soil at the depth of $0-20 \mathrm{~cm}$ from each plot randomly and then combined them into one soil sample. Three sub-samples were selected from each composite soil sample to analyze soil properties.

\subsection{Soil sampling and pre-treatment}

Soil samples were collected in September 2009. Each composite soil sample was passed through a $2-\mathrm{mm}$ sieve to remove roots and other debris, and divided into two parts. The first part was transported to the laboratory in a plastic bag on ice, and then stored at $4{ }^{\circ} \mathrm{C}$ for measurement of microbial biomass and metabolic diversity patterns; the second part was transported to laboratory, air-dried, and a portion was removed for analysis of soil physical properties, while the residual soil was sieved through $1.0-\mathrm{mm}$ and $0.25-\mathrm{mm}$ sieves, and then stored in sealed plastic bags for analysis of soil chemical properties.

\subsection{Soil analysis}

Soil bulk density was determined by the core method; soil particle size distribution was analyzed using the pipette method (ISSCAS, 1978); soil $\mathrm{pH}$ was measured using the potentiometric method with a soil-water ratio of $1: 2.5(\mathrm{w} / \mathrm{v})$; soil organic carbon (SOC) was determined with the $\mathrm{K}_{2} \mathrm{Cr}_{2} \mathrm{O}_{7}$ volumetric dilution heating method (Nelson and Sommers, 1982); total nitrogen (TN) was determined using the Kjeldahl procedure (ISSCAS, 1978); total phosphorus (TP) was determined using $\mathrm{H}_{2} \mathrm{SO}_{4}+\mathrm{HClO}_{4}$ digestion (Olsen and Sommers, 1982); total potassium (TK) was determined following the Cornfield method (Kundsen et al., 1982). Available nitrogen (AN) was determined by the alkaline diffusion method (ISSCAS, 1978); available phosphorus (AP) was exacted with $0.5 \mathrm{~mol} / 1 \mathrm{NaHCO}_{3}$ (pH 8.5) (ISSCAS, 1978); available potassium (AK) was determined using the $\mathrm{CH}_{3} \mathrm{COONH}_{4}$ extraction method (Tran and Simard, 1993). Cation exchange capacity (CEC) was determined after soil treatment with $\mathrm{CH}_{3} \mathrm{COONH}_{4}-\mathrm{C}_{2} \mathrm{H}_{5} \mathrm{OH}$; exchangeable $\mathrm{Ca}^{2+}$ and $\mathrm{Mg}^{2+}$ were determined by titration after extraction with EDTA; exchangeable $\mathrm{K}^{+}$and $\mathrm{Na}^{+}$were measured by extraction with $\mathrm{CH}_{3} \mathrm{COONH}_{4}$ and analysis of extracts with flame photometry (Thomas, 1982). Microbial biomass carbon was determined by the chloroform fumigation method (Vance et al., 1987). The metabolic diversity patterns were measured using BIOLOG (Schutter and Dick, 2001).

\subsection{Data processing and analysis}

Average well color development (AWCD) was calculated according to Garland and Mills (1991), and the substrate richness index (SRI) and Shannon's diversity index (SDI) were calculated according to Zak et al. (1994). All analyses were conducted using SPSS15.0 for Windows. Means and standard deviations (SD) were calculated for all parameters. One-way analyses of variance (ANOVA) followed by the Student-Newman-Keuls test and the least significant difference (LSD) test were performed to compare physical, chemical, and biological properties of soils among treatments. Pearson correlation analyses were also performed to test for relationships between variables. 
Table 2

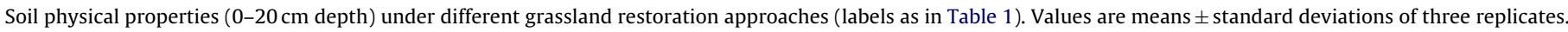
Means in a row followed by the same letter are not significantly different at $p<0.05$.

\begin{tabular}{|c|c|c|c|c|}
\hline Indicator & FG & UG & MG & CK \\
\hline Bulk density (BD) (g/cm³) & $1.51( \pm 0.15) b$ & $1.45( \pm 0.01) c$ & $1.46( \pm 0.31) b c$ & $1.62( \pm 0.05) \mathrm{a}$ \\
\hline Waterholding capacity (WHC) ${ }^{\mathrm{a}}$ & $19.27( \pm 2.43) \mathrm{b}$ & $20.72( \pm 0.46) a$ & $20.93( \pm 1.09) \mathrm{a}$ & $11.61 \pm(1.13) \mathrm{c}$ \\
\hline Sand $^{\mathrm{a}}$ & $91.89( \pm 0.56) b$ & $91.82( \pm 0.14) b$ & $91.59( \pm 0.71) b$ & $95.88( \pm 0.59) \mathrm{a}$ \\
\hline Silt ${ }^{\mathrm{a}}$ & $4.97( \pm 0.33) a$ & $4.98( \pm 0.16) \mathrm{a}$ & $5.14( \pm 0.42) \mathrm{a}$ & $2.48( \pm 0.49) b$ \\
\hline Clay $^{\mathrm{a}}$ & $3.13( \pm 0.23) b$ & $3.20( \pm 0.37) \mathrm{ab}$ & $3.26( \pm 0.30) a$ & $1.64( \pm 0.01) \mathrm{c}$ \\
\hline Total porosity ${ }^{\mathrm{a}}$ & $42.97( \pm 0.54) \mathrm{b}$ & $45.24( \pm 0.38) \mathrm{a}$ & $44.72( \pm 1.27) \mathrm{ab}$ & $38.68( \pm 1.92) \mathrm{c}$ \\
\hline
\end{tabular}

a Units: \%.

Table 3

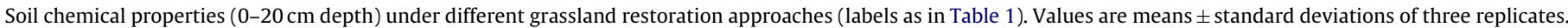
Means in a row followed by the same letter are not significantly different at $p<0.05$.

\begin{tabular}{|c|c|c|c|c|}
\hline Indicator & FG & UG & MG & CK \\
\hline $\mathrm{pH}$ & $7.34( \pm 0.05) \mathrm{a}$ & $6.58( \pm 0.11) b$ & $6.69( \pm 0.15) b$ & $6.54( \pm 0.03) b$ \\
\hline Soil organic matter (SOM) $)^{a}$ & $4.21( \pm 0.12) \mathrm{c}$ & $8.33( \pm 1.36) \mathrm{a}$ & $6.45( \pm 0.07) b$ & $0.65( \pm 0.05) \mathrm{d}$ \\
\hline Total N $(\mathrm{TN})^{\mathrm{a}}$ & $0.55( \pm 0.01) c$ & $0.79( \pm 0.01) a$ & $0.73( \pm 0.01) b$ & $0.19( \pm 0.01) \mathrm{d}$ \\
\hline Total P (TP $)^{\mathrm{a}}$ & $0.03 \mathrm{~b}$ & $0.04 \mathrm{a}$ & $0.04 \mathrm{a}$ & $0.01 \mathrm{c}$ \\
\hline Total K (TK) $)^{\mathrm{a}}$ & $22.97( \pm 1.04) b$ & $31.90( \pm 2.48) \mathrm{a}$ & $27.15( \pm 1.58) a$ & $12.73( \pm 2.79) \mathrm{c}$ \\
\hline Available $N(A N)^{b}$ & $29.17( \pm 1.17) b$ & $42.70( \pm 1.85) \mathrm{a}$ & $40.67( \pm 1.02) a$ & $8.17( \pm 1.17) \mathrm{c}$ \\
\hline Available $\mathrm{P}(\mathrm{AP})^{\mathrm{b}}$ & $0.02 b$ & $0.02 \mathrm{a}$ & $0.02 \mathrm{ab}$ & $0.01 \mathrm{~b}$ \\
\hline Available $\mathrm{K}(\mathrm{AK})^{\mathrm{b}}$ & $48.60( \pm 0.68) b$ & $65.62( \pm 2.36) \mathrm{a}$ & $57.45( \pm 2.72) \mathrm{ab}$ & $18.65( \pm 1.18) \mathrm{c}$ \\
\hline Cation exchange capacity $(\mathrm{CEC})^{c}$ & $9.76( \pm 0.19) b$ & $8.44( \pm 0.37) \mathrm{c}$ & $10.96( \pm 0.34) \mathrm{a}$ & $2.75( \pm 0.09) \mathrm{d}$ \\
\hline $\mathrm{Ca}^{2+\mathrm{C}}$ & $0.44( \pm 0.06) b$ & $0.87( \pm 0.01) a$ & $0.63( \pm 0.13) b$ & $0.12( \pm 0.01) \mathrm{c}$ \\
\hline $\mathrm{Mg}^{2+\mathrm{c}}$ & $1.18( \pm 0.29) \mathrm{a}$ & $1.12( \pm 0.10) \mathrm{a}$ & $1.43( \pm 0.08) \mathrm{a}$ & $0.68( \pm 0.08) b$ \\
\hline $\mathrm{Na}^{+\mathrm{C}}$ & $1.63( \pm 0.01) a$ & $0.63( \pm 0.17) b$ & $0.72( \pm 0.18) b$ & $0.11( \pm 0.01) c$ \\
\hline $\mathrm{K}^{+\mathrm{c}}$ & $2.56( \pm 0.01) \mathrm{a}$ & $1.71( \pm 0.11) b$ & $2.61( \pm 0.14) \mathrm{a}$ & $0.32( \pm 0.03) c$ \\
\hline
\end{tabular}

a Unit: $\mathrm{g} \mathrm{kg}^{-1}$.

b Unit: $\mathrm{mg} \mathrm{kg}^{-1}$.

c Unit: $\mathrm{cmol} \mathrm{kg}^{-1}$.

\section{Results}

\subsection{Soil physical properties}

Changes in the selected physical properties are shown in Table 2. Compared with desertified sandy grassland (CK), the other three types of grassland had significantly lower bulk density (BD), and significantly higher waterholding capacity (WHC) and total porosity. In addition, sand content was significantly lower, and silt and clay content were significantly higher in the three experimental grassland plots (FG, MG, and UG).

The fenced grassland with shelter forest (FG) had a higher bulk density than the other grassland restoration treatments, but there was no significant difference in bulk density between the artificially sparse $P$. sylvestris var. mongolica grassland (MG) and the artificially sparse $U$. pumila grassland (UG). FG had a significantly lower waterholding capacity and total porosity than MG and UG. Sand and silt content did not differ significantly with restoration treatment, but clay content was higher in FG than in UG and MG.

\subsection{Soil chemical properties}

The selected soil chemical properties are shown in Table 3. Soil $\mathrm{pH}$ was highest to lowest in the following order: $\mathrm{FG}>\mathrm{MG}>\mathrm{UG}>\mathrm{CK}$. Soil organic matter (SOM) was highest in UG and lowest in CK; moreover, there were significant differences for SOM among sampling sites. Total N, P, and K content of the three treatments were significantly higher than CK. MG and UG had significantly higher total N, P, and K than FG, but total P and K contents were not significantly different and total $\mathrm{N}$ was significantly different between MG and UG. Available N, P, and K content of the three treatments were significantly higher than CK. Available N was significantly different between FG and the two artificially sparse forest grasslands; in addition, differences in available $\mathrm{N}, \mathrm{P}$, and $\mathrm{K}$ were not significant between MG and UG. CEC, $\mathrm{Ca}^{2+}, \mathrm{Mg}^{2+}, \mathrm{Na}^{+}$, and $\mathrm{K}^{+}$were also significantly higher in the treatments than in the control; among the exchangeable cations, $\mathrm{K}^{+}$and $\mathrm{Mg}^{2+}$ were more available.

\subsection{Soil biological properties}

The selected soil biological properties are shown in Fig. 1 and Table 4 . The treatments, in order from greatest to least change in average well color development (AWCD), were as follows: $\mathrm{UG}>\mathrm{MG}>\mathrm{FG}>\mathrm{CK}$ (Fig. 1). In comparison with CK, the experimental grasslands had significantly higher microbial biomass carbon (MBC), but there were no significant differences for MBC among UG, MG, and FG. The differences in SRI and SDI were significant between the three types of restored grassland and the control. UG had the

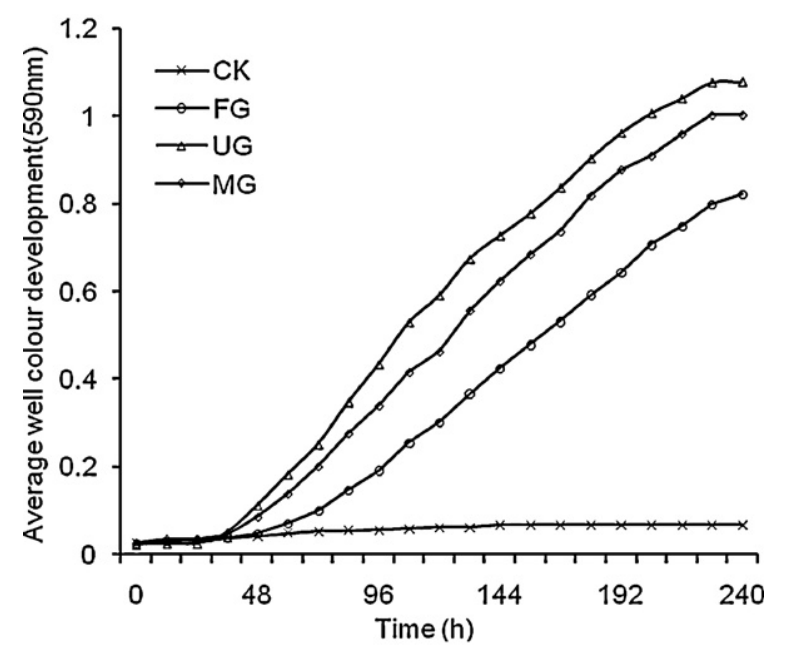

Fig. 1. Average well color development (AWCD) of microbial community in $0-20 \mathrm{~cm}$ soil (labels as in Table 1 ). 
Table 4

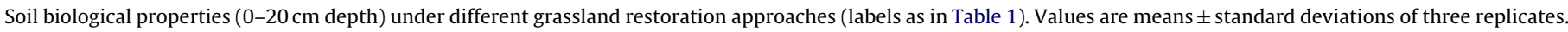
Means in a row followed by the same letter are not significantly different at $p<0.05$.

\begin{tabular}{|c|c|c|c|c|}
\hline Indicator & FG & UG & MG & CK \\
\hline $\mathrm{MBC}^{\mathrm{a}}\left(\mathrm{mg} \mathrm{kg}^{-1}\right)$ & 189.81( \pm 11.17$) a$ & $265.81( \pm 17.40) a$ & $246.53( \pm 9.64) \mathrm{a}$ & $99.06( \pm 11.32) b$ \\
\hline $\mathrm{SRI}^{\mathrm{b}}$ & $9( \pm 1.80) b$ & $14( \pm 1.27) \mathrm{a}$ & $12( \pm 1.08) a b$ & $6( \pm 1.86) c$ \\
\hline $\mathrm{SDI}^{\mathrm{C}}$ & $2.53( \pm 0.16) \mathrm{a}$ & $2.70( \pm 0.07) \mathrm{a}$ & $2.61( \pm 0.06) a$ & $1.86( \pm 0.37) b$ \\
\hline
\end{tabular}

a $\mathrm{MBC}$, microbial biomass carbon.

b SRI, substrate richness index.

c SDI, Shannon's diversity index.

Table 5

Pearson correlation coefficients among soil properties under different grassland restoration approaches (labels as in Tables 2-4).

\begin{tabular}{|c|c|c|c|c|c|c|c|c|c|c|c|c|c|c|c|c|}
\hline Variables & $\mathrm{BD}$ & WHC & Clay & Silt & Sand & $\mathrm{pH}$ & SOM & $\mathrm{TN}$ & TP & TK & AN & $\mathrm{AP}$ & $\mathrm{AK}$ & CEC & MBC & SRI \\
\hline WHC & $-0.98^{*}$ & & & & & & & & & & & & & & & \\
\hline Clay & $-0.95^{*}$ & $0.99^{* *}$ & & & & & & & & & & & & & & \\
\hline Silt & -0.94 & $0.99^{* *}$ & $0.99^{* *}$ & & & & & & & & & & & & & \\
\hline Sand & $0.95^{*}$ & $-0.99^{* *}$ & $-1.00^{* *}$ & $-1.00^{* *}$ & & & & & & & & & & & & \\
\hline $\mathrm{pH}$ & -0.11 & 0.29 & 0.39 & 0.41 & -0.40 & & & & & & & & & & & \\
\hline SOM & $-0.97^{*}$ & $0.91^{*}$ & $0.80^{* *}$ & $0.81^{* *}$ & $-0.81^{* *}$ & 0.20 & & & & & & & & & & \\
\hline $\mathrm{TN}$ & $-0.99^{* *}$ & $0.80^{* *}$ & $0.81^{* *}$ & 0.93 & -0.93 & 0.07 & $0.98^{*}$ & & & & & & & & & \\
\hline $\mathrm{TP}$ & $-0.98^{*}$ & $0.97^{*}$ & $0.87^{* *}$ & $0.80^{* *}$ & $-0.88^{* *}$ & 0.12 & $0.88^{* *}$ & $0.97^{*}$ & & & & & & & & \\
\hline TK & $-0.98^{*}$ & 0.94 & 0.90 & 0.89 & -0.89 & 0.03 & $0.99^{* *}$ & $0.98^{*}$ & 0.93 & & & & & & & \\
\hline AN & $-0.99^{* *}$ & $0.97^{*}$ & $0.88^{* *}$ & $0.89^{* *}$ & $-0.93^{* *}$ & 0.07 & $0.97^{*}$ & $0.99^{* *}$ & $0.98^{*}$ & $0.98^{*}$ & & & & & & \\
\hline $\mathrm{AP}$ & $-0.98^{*}$ & $0.98^{*}$ & $0.91^{* *}$ & $0.92^{* *}$ & $-0.96^{* *}$ & 0.21 & $0.96^{*}$ & $0.98^{*}$ & $0.95^{*}$ & $0.98^{*}$ & $0.98^{*}$ & & & & & \\
\hline AK & $-0.99^{* *}$ & $0.97^{*}$ & $0.92^{* *}$ & $0.93^{* *}$ & $-0.94^{* *}$ & 0.13 & $0.98^{*}$ & $0.99^{* *}$ & $0.95^{*}$ & $0.99^{*}$ & $0.99^{*}$ & $0.99^{* *}$ & & & & \\
\hline CEC & -0.88 & 0.95 & $0.94^{* *}$ & $0.95^{* *}$ & $-0.95^{* *}$ & 0.46 & 0.75 & 0.85 & 0.92 & 0.78 & 0.87 & 0.83 & 0.85 & & & \\
\hline $\mathrm{MBC}$ & $-0.99^{* *}$ & $0.95^{*}$ & 0.92 & 0.90 & -0.91 & 0.01 & $0.99^{* *}$ & $0.99^{* *}$ & $0.97^{*}$ & $0.99^{* *}$ & $0.99^{* *}$ & $0.97^{*}$ & $0.99^{* *}$ & 0.83 & & \\
\hline SRI & $-0.95^{*}$ & 0.88 & 0.83 & 0.81 & -0.82 & -0.15 & $0.99^{* *}$ & $0.96^{*}$ & 0.91 & $0.98^{*}$ & $0.96^{*}$ & 0.93 & $0.96^{*}$ & 0.70 & $0.98^{*}$ & \\
\hline SDI & $-0.98^{*}$ & $0.99^{* *}$ & $0.98^{*}$ & $0.98^{*}$ & $-0.98^{*}$ & 0.28 & 0.93 & $0.97^{*}$ & $0.95^{*}$ & $0.96^{*}$ & $0.97^{*}$ & $0.99^{* *}$ & $0.98^{*}$ & 0.91 & $0.96^{*}$ & 0.90 \\
\hline
\end{tabular}

* Correlation is significant at the 0.05 level.

** Significant at the 0.01 level.

highest SDI, but there were no significant differences among UG, MG, and FG. In addition, there were no differences in SRI between UG and MG.

\section{Discussion}

\subsection{Interrelationships among soil properties}

Soil is a key component of terrestrial ecosystems that not only preserves nutrient reserves and supports many biological processes, but also determines productivity and sustainability (Andrews et al., 2002; Marzaioli et al., 2010; Sharma et al., 2005). The interrelations and interactions among soil physical, chemical, and biological properties have been well studied (Powlson et al., 1987; Lowery et al., 1995). In our study, correlation analysis indicated that soil clay content had a very significant positive correlation $(p<0.01)$ with WHC, SOM, TN, TP, AN, AP, AK, and CEC. There was a significant positive correlation $(p<0.05)$ between SOM and WHC, TP, AN, AP, and AK (Table 5), which is consistent with the results of Li et al. (2004a) and Zhao et al. (2006). These results confirm that soil clay and organic matter content significantly influence retention and supply of many soil elements (Brubaker et al., 1993; Saggar et al., 2001; Wezel et al., 2000). Soil sand content had a very significant negative correlation $(p<0.01)$ with SOM, TP, TK, AN, AP, AK, and CEC (Table 5). Soil biological properties respond rapidly to soil chemical and physical changes (Islam and Weil, 2000), and our results showed a significant positive correlation $(p<0.01)$ between MBC and SOM, TN, TK, AN, and AK, and between MBC and WHC, TP, and AP $(p<0.05)$. Microbial community functional diversity was also significantly positively correlated $(p<0.05)$ with WHC, clay, silt, TN, TP, TK, AP, and AK (Table 5).

\subsection{Effects of restoration approaches on soil properties}

In this paper, we examined the effects of different grassland restoration approaches on soil properties to help assess the roles of these measures in restoration. We found that all measures used helped improve soil physicochemical and biological properties relative to the control. This result is consistent with the findings of $\mathrm{Yu}$ et al. (2002) and Su and Zhao (2003).

In the semiarid Horqin sandy grassland, continuous grazing has led to a decrease in ground cover, leaving the land surface bare and directly exposed to strong wind erosion. Wind erosion causes loss of fine soil particles and degradation of soil structure (Gomes et al., 2003; Larney et al., 1998; Lowery et al., 1995). Loss of fine soil particles may result in loss of soil organic matter and soil moisture, as well as changes in $\mathrm{pH}$ and nutrient content (Li et al., 2004a; Su et al., 2004). The establishment of artificial vegetation has been shown to protect against soil erosion by wind and enhance sand surface stabilization and soil development (Duan et al., 2004; Su and Zhao, 2003). Furthermore, artificial vegetation can enrich soil nutrients by intercepting and retaining more precipitation and aeolian dust, including atmospheric dust (Fearnehough et al., 1998; Wezel et al., 2000). Our results indicate that establishment of Populus $\times$ beijingensis, $P$. sylvestris var. mongolica, and $U$. pumila results in significant increases in silt and clay and accumulation of soil organic matter, N, P, and K. Moreover, the increased silt and clay and accumulated organic matter have led to decreased soil bulk density and increased waterholding capacity in the topsoil. We also confirmed previous findings (Shumway, 2000; Su and Zhao, 2003) that $\mathrm{C}$ and $\mathrm{N}$ fixation in artificial vegetation facilitates soil $\mathrm{C}$ buildup and $\mathrm{N}$ accumulation. Soil microorganisms were an important part of the soil and contributed to the cycling and mineralization of soil C, N, and P. An increase in soil microorganisms has been shown 
to lead to improved levels and availability of soil nutrients (Jiang et al., 2008). Our results indicate that microbial biomass $C$ and the structure and function of the soil microbial community led to significant enhancements in the artificial sparse forest and shelter forest systems.

\subsection{Differences among approaches used to restore desertified sandy grassland}

Effective restoration approaches are key to successful ecological rehabilitation. In this study, three different approaches to grassland and soil restoration were found to alleviate wind erosion and enhance sand surface stabilization. While all three approaches accelerated the improvement of sandy soils, artificial sparsely forested grassland and grassland fenced with shelter forest had significantly different impacts on soil properties. Our results indicate that soil physical and chemical properties, such as clay content, WHC, pH, total N, P, K, and available $\mathrm{N}$ were significantly higher in the UG and MG treatments than in the FG treatment, but that soil properties did not differ between UG and MG. C and N accumulation under the MG and UG treatments likely resulted in higher fertility surrounding the scattered $P$. sylvestris var. mongolica and $U$. pumila trees; this higher fertility may have gradually spread to locations between trees, so that the spatial heterogeneity of soil properties gradually decreased with increasing stand age. This effect may have been primarily the result of tree root expansion (Liu et al., 2003; Su and Zhao, 2003).

The sustainability of an artificial ecosystem is fundamental to the success of ecological rehabilitation projects (Mitchell et al., 1998), especially in the Horqin sandy land, with its poor and arid soils. Sparsely forested grassland has been found to have the highest community stability and is well suited to sandy soils in arid and semi-arid regions (Li et al., 2004b; Zhang et al., 2002). We confirmed that sparsely forested grassland functioned well in reducing wind and improving soil physical properties (Li et al., 2005). This analysis indicates that sparsely forested grassland is more effective at improving soil properties than grassland fenced a shelter forest.

\section{Conclusions}

The present study revealed that three different grassland restoration approaches improved soil physicochemical and biological properties relative to a control. Soil physical, chemical, and biological properties in two types of artificial sparsely forested grassland were better than those in grassland fenced with a shelter forest. No significant differences were found between the two types of artificial sparsely forested grassland studied here. These results suggest that the artificial sparsely forested grassland restoration approach is more effective than fencing a grassland with a shelter forest for ecological restoration of desertified sandy grasslands with poor and arid soils, such as the Horqin sandy land. Based on these results, we also conclude that it is possible to restore the degraded sandy lands by developing and adopting the artificial sparsely forested grassland restoration approach in the semi-arid and semi-humid region.

\section{Acknowledgments}

This research was funded by the National Scientific and Technical Support Program (2006BAC01A01). The authors would like to express their gratitude to the Daqinggou Ecological Station, Institute of Applied Ecology, Chinese Academy of Sciences.

\section{References}

Andrews, S.S., Karlen, D.L., Mitchell, J.P., 2002. A comparison of soil quality indexing methods for vegetable production systems in Northern California. Agric. Ecosyst. Environ. 90, 25-45.

Brubaker, S.C., Jones, A.J., Lewis, D.T., Frank, K., 1993. Soil properties associated with landscape position. Soil Sci. Soc. Am. J. 57, 235-239.

Duan, Z., Xiao, H., Li, X., Dong, Z., Wang, G., 2004. Evolution of soil properties on stabilized sands in the Tengger Desert, China. Geomorphology 59, 237-246.

Fearnehough, W., Fullen, M.A., Mitchell, D.J., Trueman, I.C., Zhang, J., 1998. Aeolian deposition and its effect on soil and vegetation changes on stabilised desert dunes in northern China. Geomorphology 23, 171-182.

Garland, J.L., Mills, A.L., 1991. Classification and characterization of heterotrophic microbial communities on the basis of patterns of community-level sole-carbonsource utilization. Appl. Environ. Microbiol. 57, 2351-2359.

Gomes, L., Arrue, J.L., Lopez, M.V., Sterk, G., Richard, D., Gracia, R., Sabre, M., Gaudichet, A., Frangi, J.P., 2003. Wind erosion in a semiarid agricultural area of Spain: the WELSONS project. CATENA 52, 235-256.

Islam, K.R., Weil, R.R., 2000. Land use effects on soil quality in a tropical forest ecosystem of Bangladesh. Agric. Ecosyst. Environ. 79, 9-16.

Institute of Soil Sciences, Chinese Academy of Sciences (ISSCAS), 1978. Physical and Chemical Analysis Methods of Soils. Shanghai Science Technology Press, Shanghai, pp. 7-59 (in Chinese).

Jiang, D.M., Cao, C.Y., Li, X., Zhou, Q., Li, M., 2008. Vegetation restoration and its effects on soil improvement in Horqin sandy land. Ecol. Environ. 17 (3), 1135-1139 (in Chinese with English abstract).

Karlen, D.L., Ditzler, C.A., Andrews, S.S., 2003. Soil quality: why and how? Geoderma $114,145-156$.

Kundsen, D., Peterson, G.A., Pratt, P.F., Page, A.L., 1982. Lithium, sodium, and potassium. In: Methods of Soil Analysis, Part 2, 2nd ed. ASA and SSSA, Madison, WI, pp. 225-246.

Larney, F.J., Bullock, M.S., Janzen, H.H., Ellert, B.H., Olson, E.C.S., 1998. Wind erosion effects on nutrient redistribution and soil productivity. J. Soil Water Conserv. 53, 133-140.

Li, F.R., Zhao, L.Y., Zhang, H., Zhang, T.H., Shirato, Y., 2004a. Wind erosion and airborne dust deposition in farmland during spring in the Horqin Sandy Land of eastern Inner Mongolia, China. Soil Till. Res. 75, 121-130.

Li, G.S., Harazono, Y., Oikawa, T., Zhao, H.L., Zong, Y.H., Chang, X.L., 2000. Grassland desertification by grazing and the resulting micrometeorological changes in Inner Mongolia. Agric. Forest Meteorol. 102, 125-137.

Li, G.T., Yao, Y.F., Zhang, D.Y., 2005. Technique system on restoration of woodland steppe in kerqin sandy land. J. Inner Mongolia Agric. Univ. 26 (3), 1-6 (in Chinese with English abstract).

Li, G.T., Yao, Y.F., Zou, S., Liu, L.C., Wei, Y.X., Jiang, P., 2004b. Studies on elm woodland steppe in Kerqin sandy land. J. Arid Resour. Environ. 18 (6), 132-138 (in Chinese with English abstract).

Li, Y.L., Cui, J.Y., Zhang, T.H., Okuro, T., Drake, S., 2009. Effectiveness of sand-fixing measures on desert land restoration in Kerqin sandy land, northern China. Ecol. Eng. 35, 118-127.

Liu, J., Zhu, X.W., Yu, F.H., Dong, M., Zhang, S.M., Wang, R.Q., 2003. Spatial heterogeneity of Ulmus pumila open forest ecosystem in otindag sandy land. Environ. Sci. 24 (4), 29-34 (in Chinese with English abstract).

Lowery, B., Swan, J., Schumacher, T., Jones, A., 1995. Physical properties of selected soils by erosion class. J. Soil Water Conserv. 50, 306-311.

Marzaioli, R., D’Ascoli, R., De Pascale, R.A., Rutigliano, F.A., 2010. Soil quality in a Mediterranean area of Southern Italy as related to different land use types. Appl. Soil Ecol. 44, 205-212.

Mitchell, D.J., Fullen, M.A., Trueman, I.C., Fearnehough, W., 1998. Sustainability of reclaimed desertified land in Ningxia, China. J. Arid Environ. 39, 239-251.

Nelson, D.W., Sommers, L.E., 1982. Total carbon, organic carbon and organic matter. In: Page, A.L., Miller, R.H., Keeney, D.R. (Eds.), Methods of Soil Analysis, Part 2. , 2nd ed. American Society of Agronomy, Madison, WI, USA, pp. 539-577.

Olsen, S.R., Sommers, L.E., 1982. Phosphorus. In: Page, A.L., Miller, R.H., Keeney, D.R. (Eds.), Methods of Soil Analysis. Part 2. Chemical and Microbiological Properties. , 2nd ed. American Society of Agronomy, Madison, WI, pp. 403-430.

Powlson, D.S., Prookes, P.C., Christensen, B.T., 1987. Measurement of soil microbia biomass provides an early indication of changes in total soil organic matter due to straw incorporation. Soil Biol. Biochem. 19, 159-164.

Saggar, S., Yeates, G.W., Shepherd, T.G., 2001. Cultivation effects on soil biological properties, microfauna and organic matter dynamics in Eutric Gleysol and Gleyic Luvisol soils in New Zealand. Soil Till. Res. 58, 55-68.

Schutter, M., Dick, R., 2001. Shifts in substrate utilization potential and structure of soil microbial communities in response to carbon substrates. Soil Biol. Biochem. 33, 1481-1491.

Sharma, K.L., Mandal, U.K., Srinivas, K., Vittal, K.P.R., Mandal, B., Grace, J.K., Ramesh, V., 2005. Long-term soil management effects on crop yields and soil quality in a dryland Alfisol. Soil Till. Res. 83, 246-259.

Shumway, S.W., 2000. Facilitative effects of a sand dune shrub on species growing beneath the shrub canopy. Oecologia 124, 138-148.

Sivakumar, M.V.K., 2007. Interactions between climate and desertification. Agric. Forest Meteorol. 142, 143-155.

Su, Y.Z., Zhao, H.L., 2003. Soil properties and plant species in an age sequence of Caragana microphylla plantations in the Horqin Sandy Land, north China. Ecol. Eng. 20, 223-235. 
Su, Y.Z., Zhao, H.L., Zhang, T.H., Zhao, X.Y., 2004. Soil properties following cultivation and non-grazing of a semi-arid sandy grassland in northern China. Soil Till. Res. 75, 27-36.

Thomas, G.W., 1982. In: Page, A.L., Miller, R.H., Keeney, D.R. (Eds.), Exchangeable Cations. Methods of Soil Analysis, Part 2. Chemical and Microbiological Properties. , 2nd ed. American Society of Agronomy, Inc., SSSA, USA, pp. 159-165.

Tran, T.S., Simard, R.R., 1993. Mehlich III-extractable elements. In: Carter, M.R. (Ed.), Soil Sampling and Methods of Analysis. Canadian Society Soil Science. Lewis Publishers, CRC Press, Boca Raton, FL, pp. 43-49.

Vance, E.D., Brookes, P.C., Jenkinson, D.S., 1987. An extraction method for measuring soil microbial biomass C. Soil Biol. Biochem. 19, 703-707.

Wezel, A., Rajot, J.L., Herbrig, C., 2000. Influence of shrubs on soil characteristics and their function in Sahelian agro-ecosystems in semi-arid Niger. J. Arid Environ. 44, 383-398.

Yu, Y., Lin, Q., Shi, Q., Liu, J., 2002. Changes of habitat and vegetation in man-made vegetation area of Shapotou section along Baotou-Lanzhou Railway. Acta Ecol. Sin. 22, 433-439.

Zak, J.C., Willig, M.R., Moorhead, D.L., Wildman, H.G., 1994. Functional diversity of microbial communities: a quantitative approach. Soil Biol. Biochem. 26, 1101-1108.

Zhang, J., Zhao, H., Zhang, T., Zhao, X., Drake, S., 2005. Community succession along a chronosequence of vegetation restoration on sand dunes in Horqin Sandy Land. J. Arid Environ. 62, 555-566.

Zhang, T.H., Zhao, H.L., Li, S.G., Li, F.R., Shirato, Y., Ohkuro, T., Taniyama, I., 2004. A comparison of different measures for stabilizing moving sand dunes in the Horqin Sandy Land of Inner Mongolia, China. J. Arid Environ. 58, 203-214.

Zhang, W.D., Jiao, S.R., Liu, Y.J., Song, B.M., Wang, M.Z., Ren, X.C., Feng, Z.F., Chen, Y.L. Xing, Z.X., 2002. Study on moving dune controlling and recovering sparse wood grassland vegetation. Prot. Forest Sci. Technol. 2, 1-4 (in Chinese with English abstract).

Zhao, H.L., Yi, X.Y., Zhou, R.L., Zhao, X.Y., Zhang, T.H., Drake, S., 2006. Wind erosion and sand accumulation effects on soil properties in Horqin Sandy Farmland, Inner Mongolia. CATENA 65, 71-79.

Zhao, Q., Zeng, D.H., Lee, D.K., He, X.Y., Fan, Z.P., Jin, Y.H., 2007. Effects of Pinus sylvestris var. mongolica afforestation on soil phosphorus status of the Keerqin Sandy Lands in China. J. Arid Environ. 69, 569-582.

Zhao, W.Z., Xiao, H.L., Liu, Z.M., Li, J., 2005. Soil degradation and restoration as affected by land use change in the semiarid Bashang area, northern China. CATENA 59, 173-186.

Zhou, R.L., Li, Y.Q., Zhao, H.L., Drake, S., 2008. Desertification effects on C and N content of sandy soils under grassland in Horqin, northern China. Geoderma $145,370-375$

Zhu, Z.D., Chen, G.T., 1994. Sandy Desertification in China Status and Trends. Science Press, Beijing, p. 250 (in Chinese).

Zhu, Z.M., Yang, C., Cao, M.M., Liu, K., Yang, L.N., 2007. Analysis on the soil factor and physiological response of the plants in the process of sandy desertification on grassland. Acta Ecol. Sin. 27, 48-56. 